\title{
Molecular Identification and Clinicopathological Findings of Hepatozoon sp. Infection in a Cat: First Report from Turkey
}

Bir Kedide Hepatozoon sp. Enfeksiyonunun Moleküler İdentifikasyonu ve Klinikopatolojisi: Türkiye' den İlk Rapor

\author{
1Department of Internal Diseases, Adnan Menderes University School of Veterinary Medicine, Aydın, Turkey \\ 2Department of Parasitology, Adnan Menderes University School of Veterinary Medicine, Aydın, Turkey \\ ${ }^{3}$ Therapy Pet Hospital, İzmir, Turkey
}

Gülten Emek Tuna ${ }^{1}$ (D), Serkan Bakırcı ${ }^{2}$, Ceren Dinler $^{1}$ (D), Gizem Battal ${ }^{3}$ (D), Bülent Ulutaş ${ }^{1}$ (D)

Cite this article as: Tuna GE, Bakırcı S, Dinler C, Battal G, Ulutaş B. Molecular Identification and Clinicopathological Findings of Hepatozoon sp. Infection in a Cat: First Report from Turkey. Turkiye Parazitol Derg 2018; 42(4): 286-9.

\section{ABSTRACT}

Hepatozoon is a genus of protozoa belonging to the phylum Apicomplexa. Ticks are the vectors for the members of this genus. The protozoans infect a wide variety of mammals, birds, reptiles, and amphibians. The domestic and wild felids are also susceptible to Hepatozoon infection. A five-year-old female cat was presented to the Adnan Menderes University, Faculty of Veterinary Medicine Animal Hospital, with a 1-month history of inappetence and weight loss. In a physical examination, weakness, depression, anorexia, lymphadenopathy, icteric mucous membranes, abdominal distension, and fever were detected. Laboratory analysis revealed anemia, neutrophilic leukocytosis, and increased serum total bilirubin and indirect bilirubin concentrations. Hepatozoonosis was diagnosed by the observation of Hepatozoon spp. gamonts within neutrophils in Giemsa-stained blood smears and confirmed by polymerase chain reaction (PCR). This is the first report about the molecular identification of hepatozoonosis in a cat from Turkey. Keywords: Cat, Hepatozoon sp., PCR, Turkey

Received: $02.06 .2018 \quad$ Accepted: 08.08 .2018

\section{Öz}

Hepatozoon türleri, keneler tarafından bulaştırılan ve çok sayıda memeli, kuş, sürüngen ve amfibiyenleri enfekte eden Apicomplexa filumuna ait protozoalardır. Evcil ve vahşi kedigiller de Hepatozoon türlerine duyarlıdır. Beş yaşında dişi bir kedi, Adnan Menderes Üniversitesi Veteriner Fakültesi Hayvan Hastanesi'ne bir aydır devam eden iştahsızık ve kilo kaybı şikayeti ile getirildi. Fiziksel muayenede güçsüzlük, depresyon, zayıflama, lenfadenopati, ikterik müköz membranlar, abdominal distension ve ateş tespit edildi. Laboratuvar analizleri anemi, nötrofilik lökositoz, artmış serum total bilirubin ve indirekt bilirubin konsantrasyonlarını ortaya koydu. Hepatozoonosis tanısı, Giemsa boyalı periferik kan yaymalarındaki nötrofiller içerisindeki Hepatozoon gametositlerinin görülmesiyle konuldu ve PCR ile teyit edildi. Bu olgu, Türkiye'de bir kedide hepatozonoosis'in moleküler tespitinin ortaya konulduğu ilk rapordur.

Anahtar Kelimeler: Kedi, Hepatozoon sp., PCR, Türkiye

Geliş Tarihi: 02.06.2018

Kabul Tarihi: 08.08.2018

\section{INTRODUCTION}

Hepatozoon species are parasites from the phylum of Apicomplexa with a definitive host (a blood-sucking invertebrate) and an intermediate host (a vertebrate) (1-3). There are more than 340 species of Hepatozoon and about 46 of them infect mammals $(2,3)$. Despite a few differences in the ecology and biology of these protozoa, the primary route of Hepatozoon species transmission to the vertebrate hosts is represented by the ingestion of the invertebrate host carry- ing mature oocysts $(1,4)$. Although the main vector of Hepatozoon spp. is the ixodid ticks, other blood-sucking invertebrates, fleas, and mosquitoes have the potential to transmit the infection. However, the vectors of feline hepatozoonosis are not exactly known (1).

Feline hepatozoonosis has been described from various countries, including Brazil, France, India, Israel, Nigeria, Portugal, Thailand, South Africa, Spain, USA, and Italy $(3,4)$. Three Hepatozoon species have been reported in felines:

A part of the study was presented at the International Turkish Veterinary Internal Medicine Congress.

Bu çalışmanın bir kısmı Uluslararası Türk Veteriner Dahiliye Kongresi'nde sunulmuştur.

Corresponding Author / Sorumlu Yazar: Gülten Emek Tuna E.mail: emektuna@adu.edu.tr DOI: $10.5152 /$ tpd.2018.5886 
Hepatozoon felis, $H$. canis, and $H$. silvestris $(2,4,5)$. A small number of epidemiological surveys have also been published (4, 6-8). Depending on the cat lifestyle, geographical area, diagnostic method used, and type of samples tested, the prevalence of infection was found to range from $0.6 \%$ to $36.8 \%$ using different methods across various regions (2-5).

Two forms of the parasite have been found in the cat: intracellular gamonts in neutrophils and monocytes and meronts in several tissues (3). Hepatozoonosis is usually diagnosed by detecting the gamonts in blood smears and by identifying meronts in biopsy specimens (3). However, the parasitemia degree is low in cats (less than 1\%) (9). Hence, it is often overlooked in blood smears. In recent years, with the development of molecular tech-

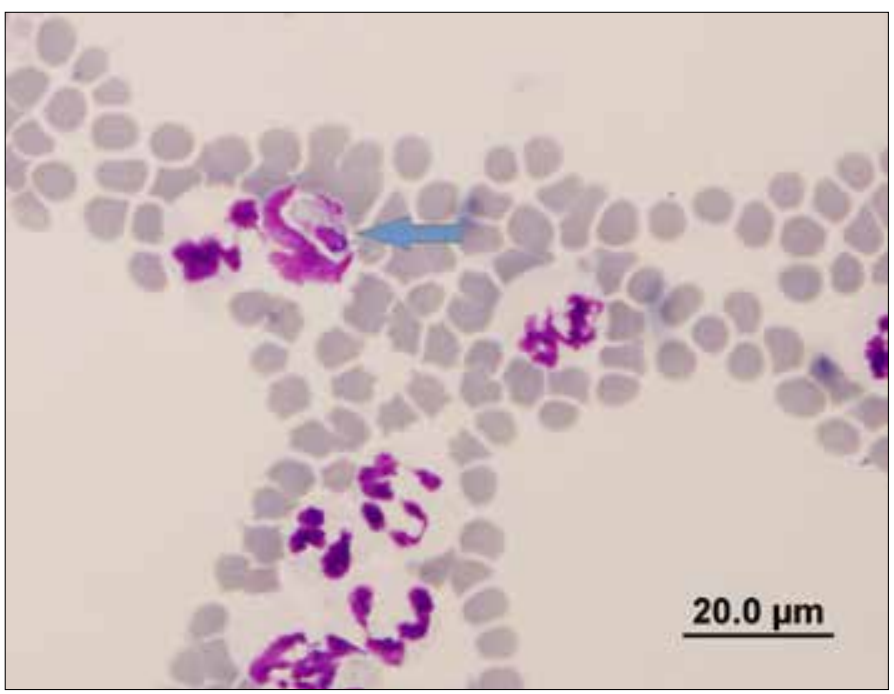

Figure 1. Hepatozoon spp. gamont in neutrophils from Giemsa stained peripheral blood smear. Scale bar $=20 \mu \mathrm{m}$

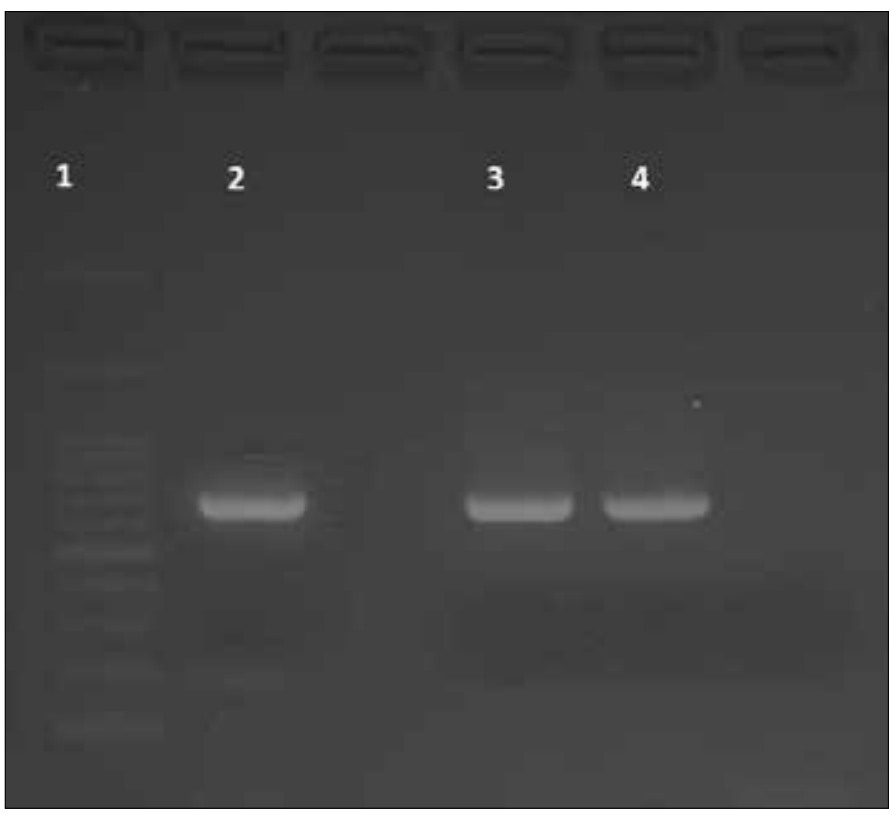

Figure 2. PCR amplification of a partial sequence of the Hepatozoon spp. from the cat

1: Marker, 2: Sample, 3 and 4: positive control niques, PCR has been started to be used for the diagnosis of Hepatozoon spp. in cats. Molecular methods are more sensitive and specific than the blood smear method for the detection of Hepatozoon spp. (1, 3).

In Turkey, although hepatozoonosis is widespread in dogs (1013), feline hepatozoonosis has not yet been documented. This case is the first report of molecular identification of Hepatozoon spp. infection in a domestic cat from Turkey.

\section{CASE REPORT}

A five-year-old female cat was presented to the Veterinary Teaching Hospital, Adnan Menderes University, with a 1-month history of inappetence and weight loss. The cat was living indoors with access to the outdoors. Vaccination and antiparasitic treatment program of the cat were irregular. The cat was fed with commercial food and did not have any serious health problems until 3 weeks ago. Three weeks before the presentation, the cat was

Table 1. Hemato-biochemical findings of the cat naturally infected with Hepatozoon spp.

\begin{tabular}{|c|c|}
\hline Parameters & Values \\
\hline WBC $\left(\times 10^{3}\right.$ cells $\left./ \mu \mathrm{L}\right)$ & 59.10 \\
\hline Lymphocytes $\left(\times 10^{3}\right.$ cells $\left./ \mu \mathrm{L}\right)$ & 0.50 \\
\hline Monocytes $\left(\times 10^{3}\right.$ cells $\left./ \mu \mathrm{L}\right)$ & 2.83 \\
\hline Neutrophils $\left(\times 10^{3}\right.$ cells $\left./ \mu \mathrm{L}\right)$ & 54.38 \\
\hline Lymphocytes (\%) & 0.8 \\
\hline Monocytes (\%) & 4.4 \\
\hline Neutrophils (\%) & 92.0 \\
\hline $\mathrm{RBC}\left(\times 10^{6}\right.$ cells $\left./ \mu \mathrm{L}\right)$ & 3.84 \\
\hline Hemoglobin (g/dL) & 6.4 \\
\hline Hematocrit (\%) & 18.19 \\
\hline $\mathrm{MCV}(\mathrm{fL})$ & 47 \\
\hline $\mathrm{MCH}(\mathrm{p} / \mathrm{g})$ & 16.5 \\
\hline $\mathrm{MCHC}(\mathrm{g} / \mathrm{dL})$ & 34.9 \\
\hline Platelets $\left(\times 10^{3}\right.$ cells $\left./ \mu \mathrm{L}\right)$ & 771 \\
\hline Glucose (mg/dL) & 75 \\
\hline AST (U/L) & 13 \\
\hline ALT (U/L) & 21 \\
\hline $\operatorname{ALP}(U / L)$ & 170 \\
\hline GGT (U/L) & 9 \\
\hline Total protein (g/dL) & 6 \\
\hline Albumin & 2.4 \\
\hline Direct Bilirubin (mg/dL) & 1.9 \\
\hline Total Bilirubin (mg/dL) & 4.76 \\
\hline Urea $(\mathrm{mg} / \mathrm{dL})$ & 42 \\
\hline Creatinine $(\mathrm{mg} / \mathrm{dL})$ & 0.75 \\
\hline \multicolumn{2}{|c|}{$\begin{array}{l}\text { WBC: white blood cells; RBC: red blood cell; MCV: mean } \\
\text { corpuscular volume; MCH: mean corpuscular hemoglobin; MCHC } \\
\text { mean corpuscular hemoglobin concentration; AST: aspartate } \\
\text { aminotransferase; ALT: alanine aminotransferase; GGT: gamma- } \\
\text { glutamyltransferase }\end{array}$} \\
\hline
\end{tabular}


treated for a hepatic/post hepatic icterus in a private clinic, but no improvement was observed. In a physical examination of the cat presented to our hospital, weakness, depression, anorexia, fever $\left(40.5^{\circ} \mathrm{C}\right)$, lymphadenopathy, tachycardia, icteric mucous membranes, and abdominal distension were observed.

Three blood samples were collected from the cephalic vein for hematological, biochemical, and molecular examinations and for the detection of feline leukemia virus (FeLV) antigen and antibodies to feline immunodeficiency virus (FIV). The hematological abnormalities were moderate anemia and neutrophilic leukocytosis (Table 1). The serum biochemical abnormalities included elevated direct and total bilirubin concentrations (Table 1). The FIV antigen test by using rapid diagnostic commercial test kit (Fassisi® FeLFIV, Germany) was positive. To assess the cause of the abdominal distension, abdominal radiography and ultrasonography were performed. The radiography revealed increased soft tissue density in the proximal abdomen and numerous dilated bowel loops filled with gas and feces. The ultrasonography of the cranial abdomen showed marked hepatomegaly and a normal gallbladder structure. Caudal abdominal ultrasonography was unremarkable. Giemsa-stained blood smears were prepared and examined under the light microscope. The blood smears revealed Hepatozoon spp. gamonts within the neutrophils (Figure 1). The gamonts measured $9.72 \pm 0.80 \mu \mathrm{m}$ in length and $4.17 \pm 0.09 \mu \mathrm{m}$ in width. The slides were also used to examine leukocyte differentiation, erythrocyte morphology, and other infectious agents.

Written informed consent was obtained from cat's owner who participant in this case. PCR was performed to confirm Hepatozoon sp. infection (Figure 2). The DNA was extracted from each of two ethylenediaminetetraacetic acid-containing blood samples using the Promega Wizard genomic DNA extraction kit (Madison, WI, USA) following the manufacturer's instructions. Two microliters of extracted DNA were used for PCR amplification. Primers HepF (5'-ATA-CAT-GAG-CAA-AAT-CTC-AAC-3') and HepR (5'-CTT-ATT-ATT-CCA-TGC-TGC-AG-3'; Thermo Electron $\mathrm{GmbH}$, Germany), which amplify a 666 bp fragment of the 18S rRNA gene of Hepatozoon spp., were used according to Inokuma et al., (14). The PCR product was electrophoresed on a $1.5 \%$ agarose gel and visualized under ultraviolet light.

Following the diagnosis, intravenous fluid therapy, doxycycline (5 $\mathrm{mg} / \mathrm{kg}$ /once a day), lactulose ( $5 \mathrm{~mL} / \mathrm{cat}, \mathrm{PO}$, twice a day), ursodeoxycholic acid $(10 \mathrm{mg} / \mathrm{kg}$ once a day), B complex vitamins (1.0 $\mathrm{mL} / \mathrm{cat}$, once a day), and vitamin C (200 mg/cat, once a day) were prescribed. Prescribed drugs were not administered by the cat owner because the cat had escaped and she died. A postmortem pathological examination could not be performed.

\section{DISCUSSION}

Tick-borne diseases are caused by a vast number of agents, including viruses, bacteria, and parasites. Although these diseases are more common in dogs, they are rarely reported in cats because cats are more resistant to tick-borne diseases. This situation is related to the specific behavior of cats and the mechanical removal of ticks from their body surface during grooming. Also, cats are likely to have innate resistance or adaptation to infec- tion, restriction of the disease progression, or the transmission of the infectious agents $(15,16)$.

Hepatozoon infection in a domestic dog was first described by the Nevzat (17) in Turkey. The first clinical case of $H$. canis infection in a dog was reported by Voyvoda et al. (18). Several epidemiological surveys have revealed a high prevalence of $H$. canis in dogs in Turkey (10-13). The studies indicated that the prevalence of $H$. canis infection in dogs varies as 22.3-54.3\%. Although canine hepatozoonosis caused by $\mathrm{H}$. canis occurs commonly, Hepatozoon spp. in cats have not been reported in Turkey. We report the first case of Hepatozoon sp. infection in a cat in Turkey in this case.

Feline hepatozoonosis is usually associated with outdoor access where contact with ticks is more frequent compared to strictly indoor cats $(2,3,5)$. In our case, we found no ticks on clinical examination, but since the cat lived in outdoor access, she might have had contact with ticks. The transmission of Hepatozoon in cats is not yet fully understood. However, Aktas (19) detected H. felis DNA in Rhipicephalus sanguineus tick in Turkey. Unlike other tick-borne protozoan and bacterial disease, Hepatozoon infection in a dog occurs by the ingestion of the infected ticks, and it is presumed that cats are infected by the same route (15).

In cats, the infection has a low virulence, mostly subclinical, and there is scarce clinical information on the disease $(2,5,20)$. As in dogs with hepatozoonosis, the identification of a characteristic clinical syndrome in feline hepatozoonosis is difficult. The most common clinical findings of feline hepatozoonosis are nonspecific, including fever, anorexia, weakness, weight loss, lymphadenopathy, lethargy, and icterus $(2,14,15)$. The clinical signs of the cat presented here were similar to those reported for cats with Hepatozoon sp. infection by other investigators $(9,20)$. The presence of co-infections with FeLV or FIV, other causes of immunosuppression, and other vectorborne pathogens have frequently been described in feline hepatozoonosis $(5,21)$. Similar with those reports, FIV and possible immunosuppression related to FIV could also play an important role in this case. A few studies have indicated that co-infections may enhance the virulence of Hepatozoon spp. $(9,22)$. Also, immunosuppression may increase the degree of parasitemia $(2,23)$.

In the present case, the results of laboratory tests revealed neutrophilic leukocytosis, moderate anemia, and bilirubinemia. Anemia and leukocytosis with neutrophilia in our case were similar with those previously reported $(3,9)$, and those alterations could be related to secondary necrosis and inflammation in the spleen, lymph nodes, liver, and lungs because of meronts observed in many tissues, such as the skeletal muscle, myocardium, lung, liver, pancreas, bone marrow, and lymph node $(3,9)$. Elevated serum total and direct bilirubin levels detected in our case may be related to the presence of developmental stages of the agent in the liver and hemolysis.

Nonspecific and broad clinical findings of the disease make it difficult to confirm the diagnosis based exclusively on clinical assessment. Hence, definitive diagnosis of feline hepatozoonosis is mainly performed by the determination of Hepatozoon spp. gametocytes within neutrophils and monocytes in stained blood smears. Because of low parasitemia, PCR should be considered 
the diagnostic test of choice for confirming Hepatozoon infection (3). In this case, the diagnosis was confirmed by the detection of gamonts in Giemsastained blood smears and by PCR.

\section{CONCLUSION}

This case is the first molecular identification of Hepatozoon sp. in a cat from Turkey. This infection should be considered in cats with inappetence, weight loss, anemia, icterus, and leukocytosis. Further studies are needed to understand hepatozoonosis in cats in Turkey.

Peer-review: Externally peer-reviewed.

Author Contributions: Concept - G.E.T., B.U.; Design - G.E.T.; Supervision - B.U.; Resources - G.E.T., G.B.; Materials -G.E.T., S.B.; Data Collection and/or Processing - S.B., C.D., G.B.; Analysis and/or Interpretation - G.E.T., S.B..; Literature Search -C.D., G.B.; Writing Manuscript - G.E.T., B.U.; Critical Review - G.E.T., S.B., B.U.

Conflict of Interest: Authors have no conflicts of interest to declare.

Financial Disclosure: The authors declared that this study has received no financial support.

Hakem Değerlendirmesi: Dış bağımsız.

Yazar Katkıları: Fikir - G.E.T., B.U.; Tasarım -G.E.T.; Denetleme - B.U.; Kaynaklar - G.E.T., B.U.; Malzemeler - G.E.T., S.B.; Veri Toplanması ve/ veya İşlemesi - S.B., C.D., G.B.; Analiz ve/veya Yorum - G.E.T., S.B.; Literatür Taraması - C.D., G.B.; Yazıyı Yazan - G.E.T., B.U.; Eleştirel İnceleme - G.E.T., S.B., B.U

Çıkar Çatışması: Yazarlar çıkar çatışması bildirmemişlerdir.

Finansal Destek: Yazarlar bu çalışma için finansal destek almadıklarını beyan etmişlerdir.

\section{REFERENCES}

1. Baneth G. Perspectives on canine and feline hepatozoonosis. Vet Parasitol 2011; 181: 3-11 [CrossRef]

2. Baneth G, Sheiner A, Eyal O, Hahn S, Beaufils JP, Anug Y, et al. Redescription of Hepatozoon felis (Apicomplexa: Hepatozoidae) based on phylogenetic analysis, tissue and blood from morphology, and possibly transplacental transmission. Parasit Vectors 2013; 6: 102. [CrossRef]

3. Lloret A, Addie DD, Boucraut-Baralon C, Egberink H, Frymus $T$, Gruffydd-Jones T, et al. Hepatozoonosis in cats: ABCD guidelines on prevention and management. J Feline Med Surg 2015; 17: 642-4. [CrossRef]

4. Giannelli A, Latrofa MS, Nachum-Biala Y, Hodžić A, Greco G, Attanasi $A$, et al. Three different Hepatozoon species in domestic cats from southern Italy. Ticks Tick Borne Dis 2017; 8: 721-4. [CrossRef]

5. Díaz-Regañón D, Villaescusa A, Ayllón T, Rodríguez-Franco F, Baneth G, Calleja-Bueno L, et al. Molecular detection of Hepatozoon sp. and Cytauxzoon sp. in domestic and stray cats from Madrid, Spain Parasit Vectors 2017; 10: 112. [CrossRef]

6. Jittapalapong S, Rungphisutthipongse O, Maruyama S, Schaefer JJ, Stich RW. Detection of Hepatozoon canis in stray dogs and cats in Bangkok, Thailand. Ann NY Acad Sci 2006; 1081: 479-88. [CrossRef]

7. Tabar MD, Altet L, Francino O, Sánchez A, Ferrer L, Roura X. Vector-borne infections in cats: Molecular study in Barcelona area (Spain). Vet Parasitol 2008; 151: 332-6. [CrossRef]

8. Vieira RFC, Biondo AW, Guimarães AMS, Santos AP, Santos RP, Dutra LH, et al. Ehrlichiosis in Brazil. Rev Bras Parasitol Vet 2011; 20: 1-12. [CrossRef]

9. Baneth G, Aroch I, Tal N, Harrus S. Hepatozoon species infection in domestic cats: A retrospective study. Vet Parasitol 1998; 79: 123-33. [CrossRef]

10. Karagenc TI, Pasa S, Kirli G, Hosgor M, Bilgic HB, Ozon YH, et al. A parasitological, molecular and serological survey of Hepatozoon canis infection in dogs around the Aegean coast of Turkey. Vet Parasitol 2006; 135: 113-9. [CrossRef]

11. Aktas M, Ozubek S, Altay K, Balkaya I, Utuk AE, Kırbas A, et al. A molecular and parasitological survey of Hepatozoon canis in domestic dogs in Turkey. Vet Parasitol 2015; 209: 264-7. [CrossRef]

12. Aktas $\mathrm{M}$, Ozubek $\mathrm{S}$. A survey of canine haemoprotozoan parasites from Turkey, including molecular evidence of an unnamed Babesia. Comp Immunol Microbiol Infect Dis 2017; 52: 36-42. [CrossRef]

13. Orkun O, Koç N, Sürsal N, Çakmak A, Nalbantoğlu S, Karaer Z. Molecular Characterization of Tick-Borne Blood Protozoa in Stray Dogs from Central Anatolia Region of Turkey with a High-Rate Hepatozoon Infection. Kafkas Univ Vet Fak Derg 2017; 24: 227-32.

14. Inokuma H, Okuda M, Ohno K, Shimoda K, Onishi T. Analysis of the $18 \mathrm{~S}$ rRNA gene sequence of a Hepatozoon detected in two Japanese dogs. Vet Parasitol 2002; 106: 265-71. [CrossRef]

15. Shaw SE, Birtles RJ, Day MJ. Arthropod-transmitted infectious diseases of cats. J Feline Med Surg 2001; 3: 193-209. [CrossRef]

16. Oliveira LS, Mourão LC, Oliveira KA, Agostini MM, Oliveira AC, Almeida MR, et al. Molecular detection of Ehrlichia canis in cats in Brazil. Clin Microbiol Infec 2009; 15: 53-4. [CrossRef]

17. Nevzat A. Bizde ilk defa görülen bik (Hepatozoon canis) vak'ası. Türk Baytarlar Cemiyeti Mecmuası 1933; 3: 5 .

18. Voyvoda H, Pasa S, Unver A. Clinical Hepatozoon canis infection in a dog in Turkey. J Small Anim Pract 2004; 45: 613-7. [CrossRef]

19. Aktas M. A survey of ixodid tick species and molecular identification of tick-borne pathogens. Vet Parasitol 2014; 200: 276-83. [CrossRef]

20. Perez RR, Rubini AS, O'Dwyer LH. The first report of Hepatozoon sp. (Apicomplexa, Hepatozoidae) in domestic cats from Säo Paolo state, Brazil. Parasitol Res 2004; 94: 83-5. [CrossRef]

21. Maia C, Ferreira A, Nunes M, Vieira ML, Campino L, Cardoso L. Molecular detection of bacterial and parasitic pathogens in hard ticks from Portugal. Ticks Tick Borne Dis 2015; 5: 409-14. [CrossRef]

22. Kubo M, Miyoshi N, Yasuda N. Hepatozoonosis in two species of Japanese wild cat. J Vet Med Sci 2006; 68: 833-7. [CrossRef]

23. Beaufils JP, Martin-Granel J, Jumelle P. Hepatozoon spp. parasitemia and feline leukaemia virus infection in two cats. Feline Pract 1998; 26: 10-3 